\title{
DOES EXPERIMENTAL NON-RECLAIMED SITES DIFFER FROM TECHNICALLY RECLAIMED AREAS IN THE RISK OF ARTIFICIAL BIRD NEST PREDATION? A CASE STUDY IN RADOVESICKÁ SPOIL HEAP
}

\author{
JAKUB NOVÁK * AND MARKÉTA HENDRYCHOVÁ \\ Department of Landscape and Urban Planning, Faculty of Environmental Sciences, Czech \\ University of Life Sciences Prague, Kamýcká 129, Praha - Suchdol, 165 00, Czech \\ Republic \\ *Corresponding author: Jakub Novák, e-mail address: novakjakub@fzp.czu.cz
}

Received: $15^{\text {th }}$ January 2021, Accepted: $5^{\text {th }}$ April 2021

\begin{abstract}
Areas left to natural development have been found to be sites with higher diversity and conservation value of local communities, including bird communities, compared to artificial reclamation of post-industrial areas. Most of the studies conducted so far have focused primarily on bird communities of post-mining areas, in terms of the diversity and richness of species. Our study dealt with bird nest predation on specific case of two experimental sites (20 and 32 ha) with more than a 20-year history of primary spontaneous succession established within the technical reclamation of the Radovesická spoil heap (approx. 1,200 ha, North Bohemia, Czech Republic). In the spring of 2018, we conducted a predation experiment using artificial nests (ground and elevated), installed within both succession areas and beyond, in the adjacent artificially reclaimed areas. We monitored the way of restoration and the distance of the nest placement from the succession-reclamation sites edge. The rate of predation was very high: $92.5 \%$ in reclaimed area and $89.4 \%$ in spontaneous successions. None of the observed factors analysed in the generalised linear model (GLM) have conclusively explained the risk of predation. The two experimental succession sites did not differ from the surrounding reclaimed sites in terms of the risk of predation, nor did they significantly influence predation risk on reclaimed sites. We believe that both relatively small and mutually isolated areas do not provide enough of an inner environment without or with at least a limited effect of predation pressure coming from adjacent reclaimed areas.
\end{abstract}

Keywords: predation risk, spontaneous development, technical reclamation, nest predator, matrix effect

\section{INTRODUCTION}

Bird nest predation is considered to be one of the major factors behind the decline of avifauna (e.g. Ricklefs, 1969 or Martin, 1993). It may cause a loss of up to $80 \%$ of nests (Martin, 1993). Among other things, increased nest predation is due to landscape fragmentation (e.g. Donovan et al., 1997; Stephens et al., 2004). In addition to the direct loss of habitats or shrinking and deepening isolation of individual habitat patches (e.g. Wilcox \& 
Novák J., Hendrychová M.: Does experimental non-reclaimed sites differ from technically reclaimed areas in the risk of artificial bird nest predation? A case study in Radovesická spoil heap

Murphy, 1985), the influence of the edge effects (Paton, 1994) is emphasised in ecotone between two adjacent habitats making the ecoton an "ecological trap" for the nesting birds that are exposed to higher predation pressure in the ecoton (Gates \& Gysel, 1978; Chalfoun et al., 2002).

Reclamation of post-mining areas is aimed at restoring the landscapes disturbed or completely destroyed by extraction, including the restoration of functional and stable ecosystems (Hüttl \& Gerwin, 2005; Macdonald et al., 2015). In addition to technical, agricultural, forestry or hydric reclamation, near-natural methods of restoration or even leaving at least part of the area to a natural spontaneous succession are being increasingly applied (e.g. Bradshaw \& Hüttl, 2001; Hodačová \& Prach, 2003; Tischew \& Kirmer, 2007; Prach \& Hobbs, 2008; Baasch et al., 2012). The landscape disturbed by mining activities creates new habitats that are immediately spontaneously occupied by plant, invertebrate and vertebrate colonisers (e.g. Prach \& Pyšek, 2001; Bröring \& Wiegleb, 2005; Kirmer et al., 2008). These succession areas are found to be sites with higher diversity and conservation value of local communities, as compared to artificial reclamation, especially the early stages of succession (Prach et al., 2011; Hendrychová et al., 2012; Hendrychová \& Bogusch, 2016, Hendrychová et al., 2020).

The described phenomena are also valid for bird communities (Bejček \& Št’astný, 1984). In terms of nature conservation, the early stages of succession, i.e. the open habitats without or with sparse vegetation cover are the most important (Clavero et al., 2011; Śálek, 2012). However, later succession stages are also valuable as they usually outperform technically reclaimed areas with their biodiversity (Hendrychová et al., 2009; Śálek, 2012). Most of the conducted studies focused on bird communities of post-industrial habitats mainly in terms of diversity and richness of species (e.g. Karr, 1968; Bejček \& Št’astný, 1984; Hendrychová et al., 2009; Clavero et al., 2011; Šálek, 2012). Fewer studies (e.g. Purger et al., 2004 a, b) have dealt with nesting success or predation directly in post-industrial mining areas.

During a pilot research conducted in 2016, we recorded a very high predation rate $84.4 \%$ (76 of 90, p < 0.0001) of experimental artificial bird nests in the Radovesická spoil heap a reclaimed post-mining locality in the Czech Republic. We also noted a possible positive effect of the present experimental succession areas. The predation rate in these areas reached $66.7 \%$ ( 4 of $6, p=0.4142$ ), but due to the small number of nests located here, it was inconclusive (Novák, 2017). Therefore, two years later we focused directly on those experimental sites. The aim of this study was to investigate the relative risk of nest predation in the restored post-mining site primarily depending on the way of the restoration (spontaneous succession vs. technical reclamation). The intention was to find out whether the risk of nest predation on the successional areas differs from the risk of nest predation in the artificially reclaimed areas and whether the presence of succession areas may affect the risk of nest predation in artificially reclaimed areas.

\section{MATERIAL AND METHODS}

\section{Study area}

The study area is located on the Radovesická spoil heap $\left(50^{\circ} 32^{\prime} 34.507^{\prime \prime N}\right.$, $\left.13^{\circ} 49^{\prime} 53.891^{\prime \prime E}\right)$ situated in the Most Basin in Northern Bohemia in the Czech Republic, in the region affected by intensive lignite surface mining. Between 1964 and 2003, it was used to deposit overburden soils from the nearby surface mine. In total, almost 680 million $\mathrm{m}^{3}$ of overburden, mainly sand-clay soils, were deposited here. The surface of the heap occupies an area of 1,200 ha. Since 1986, technical reclamation of the area has been gradually 
progressing. Surface landscaping has been carried out, as well as fertilisation of the upper layers of soils, road construction, drainage channels, erosion control measures and biological reclamation. Two mutually isolated research areas were left for continuing natural succession in the middle of the spoil heap: the southern area of 32 hectares since 1998; and the northern area of 20 hectares since 1990 (Figure 1). The smallest distance between the two areas is $833 \mathrm{~m}$. The distance of the succession areas to the edge of the spoil heap is $278 \mathrm{~m}$ at the north and $551 \mathrm{~m}$ at the south. The wide vicinity of the succession areas is completely made up of agricultural or forestry reclamations with a levelled surface and dominant permanent grasslands established by sowing clover-grass mixtures poor in species, only minimally complemented by a young forest plantations. Solitary trees and small water bodies were left sporadically on grasslands during reclamation. In contrast with these large grassy plains, both succession areas have never undergone landscaping or fertilisation of the upper soil layers, and both have a very varied microrelief of the surface. It is composed of characteristic dunes, i.e. parallel strips of deposited spoil heap soil alternated with terrain depressions. A number of smaller and larger natural water bodies and wetlands have formed in these depressions. The "sharp" edge in between the technically reclaimed area and both succession areas is highlighted by the presence of service roads.

Fig. 1: Radovesická spoil heap location in the Czech Republic (a) and aerial map (b) with highlighted boundaries of the spoil heap (dashed line) and both non-reclaimed experimental sites (full line).

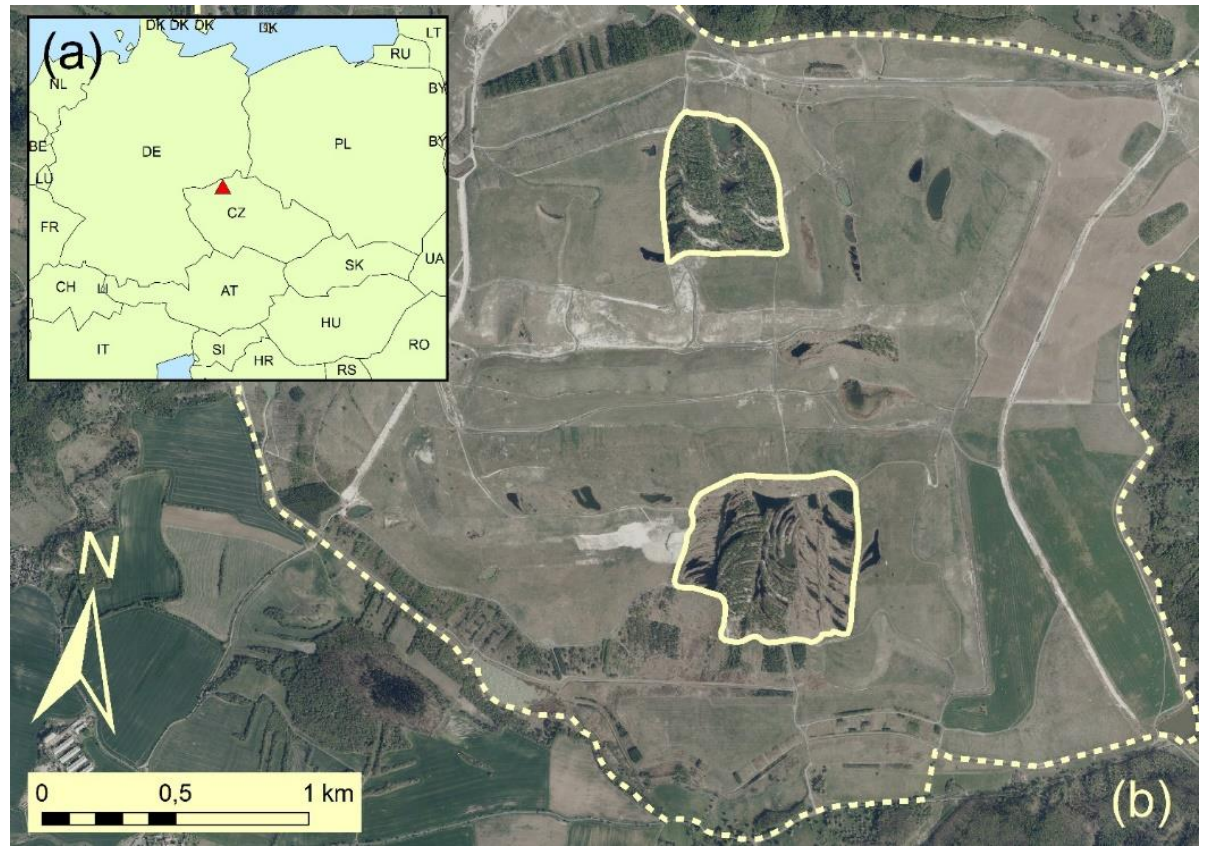

The naturally formed vegetation of succession areas has an open forest-steppe character with small vegetation free sites. Vertical and horizontal vegetation structure is very diversified (vegetation structure determined by remote sensing methods (LiDAR) and bird community of Radovesická spoil heap were also well described by Moudrý et al., 2021). Spontaneously developing habitats are dominated by grows of European birch (Betula pendula), aspen (Populus tremula), goat willow (Salix caprea) and other shrubs. The bush 
Novák J., Hendrychová M.: Does experimental non-reclaimed sites differ from technically reclaimed areas in the risk of artificial bird nest predation? A case study in Radovesická spoil heap

grass (or also wood small-reed) (Calamagrotidis epigejos) is typical of grassy parts. Common reed (Phragmites australis) is often found in waterlogged depressions (Prach \& Pyšek, 2001; personal observation). The northern succession site is more covered with denser woody growth and contains some sandy sites without vegetation. The southern succession site has a character of more opened grasslands with dispersed woody growth and larger number of water bodies (Figure 2). Bird communities are represented by species typical of individual succession stages, complemented by other common species (Hendrychová et al., 2009). In total, 34 species including 14 species specially protected in the Czech Republic were found in succession areas (Š́lek, 2012).

Fig. 2: Aerial photos of northern succession site (a), southern succession site (b), technical reclaimed areas be agricultural reclamation (c) or afforestation (d) and surrounding landscape (e).
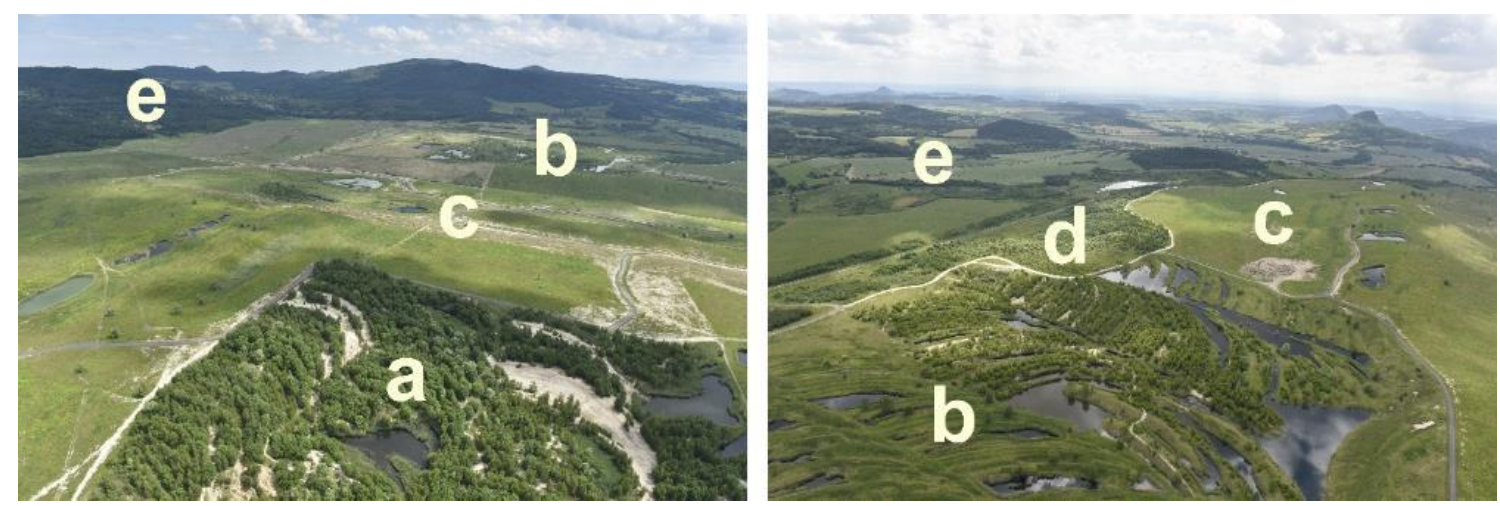

\section{Research design}

We used artificial ground nests and, in the case of both succession areas with the presence of trees, even elevated nests. We consider the use of artificial nests to be justified alternative to natural nests, since we did not investigate the rate of nest predation in a particular bird species but rather the relative risk of nest predation depending on the post-mining area management (Major \& Kendal, 1996; Pärt \& Wretenberg, 2002; Zanette, 2002).

At the beginning of May 2018, we installed a total of 173 experimental nests: 80 in technically reclaimed areas; 46 (23 ground and 23 elevated) in the northern succession area, and 47 ( 25 ground and 22 elevated) in the southern succession area. The nests were housed in a total of 16 pre-defined line transects leading in various directions roughly perpendicular to the edge between the succession area and the technically reclaimed area. The nests were placed approximately at the edges and then further at different distances from the edge to the outside and inside of both succession areas (Paton, 1994; Reino et al., 2010). In the reclaimed areas, the remotest nest was located 509 meters from the edge. It was at a distance of only $218 \mathrm{~m}$ inside the succession areas, for spatial reasons. For easier searching, each site was labelled by sign in the form of a strip of unobtrusive colour, tied to a branch or a twig pinned in the ground at a distance of about $5 \mathrm{~m}$ from the installed nest (Major \& Kendal, 1996).

Created nests very closely simulated the nests of birds nesting on the ground, such as Eurasian skylark (Alauda arvensis), whinchat (Saxicola rubetra) or tree pipit (Anthus trivialis), as well as the birds nesting in trees or bushes, such as Eurasian blackbird (Turdus merula), song thrush (Turdus philomelos) or Eurasian blackcap (Sylvia atricapilla). All 
species were observed in the study area (Š́lek, 2012). The ground nests most often had the form of a shallow pit in the ground with a size of about $10 \mathrm{~cm}$ in diameter, laid out with local dry plant material. The elevated nests were made in advance as a shallow open dish with a diameter of about $10 \mathrm{~cm}$, depth of about $5 \mathrm{~cm}$, and an inner structure woven from metal wires, lined by a mixture of clay and dry grass, and wrapped with dry plant material. Each nest was filled with two eggs of Japanese quail (Coturnix japonica) and one plasticine egg of inconspicuous grey colour, corresponding to the quail egg in size and shape, allowed to detect predators through the imprints in the plasticine egg (Major \& Kendal, 1996; Maier \& Degraaf, 2000). The plasticine eggs were fixed in the ground nests with a $12 \mathrm{~cm}$ nail pinched in the ground (with the head masked by plasticine) and attached to the nest structure with a wire in the case of the elevated nests made it difficult for the eggs to be removed from the nest (Suvorov et al., 2014). All materials and aids were allowed to ventilate in the open air for two weeks (Purger et al., 2004a) and we always used latex gloves to minimise the influence of human door transmission (Whelan et al., 1994; Reino et al., 2010; Sánchez-Oliver et al., 2014).

During the installation we made a photographic documentation of each nest with a nest concealment reading card (similar to Donovan et al., 1997). One photograph of the nest was taken from a height of about $1 \mathrm{~m}$ and another from a distance of about $5 \mathrm{~m}$ from four different, preferably mutually perpendicular directions, from an adult standing height. The concealment of the nests was optometrically detracted on a scale of 0 to $100 \%$ (Remeš, 2005). In elevated nests, their height above the ground in $\mathrm{cm}$ was also registered.

The nests were exposed to predators for two weeks, which corresponds to the incubation period of many songbirds in the Czech Republic. Each nest was revisited after installation only for the check-up to reduce the effect of the observer and to keep its site hidden as far as possible from predators (Major, 1990). The fate of the nest was registered: (1) non-predated; (2) predated (if at least one of the eggs was taken away or damaged); (3) excluded from the research (if the nest was demonstrably destroyed by human activity). A possible predator of eggs and nests was determined in the taxonomic class of a mammal or a bird.

The data obtained was analysed in the $\mathrm{R}$ application, version 3.5.1 (R Development Core Team, 2018). We used the chi-squared test for goodness of fit to compare the difference between the numbers of predated and non-predated nests and between the number of nests predated by mammals or birds within one locality or one type of nest. To compare nest predation rates and the proportional representation of predators between the sites and between both types of experimental nests, Pearson's chi-squared test with Yates' continuity correction for $2 \times 2$ contingency tables were used. The average values of nest concealment in both types of environments were compared by a two-sample t-test. The probability of nest predation was analysed in a generalised linear model (GLM), in which the fate of the nest $(1=$ predated, $0=$ non-predated $)$ was the explained variable with binomial distribution. The relevance of the explanatory variables was tested by the chi-squared test. We have created two separate models for nests located in reclaimed areas and nests in succession areas. Both models consistently included explanatory variables of the smallest nest distance to the edge between the reclaimed and succession areas and the nest cover. In addition, the nest height above the ground was included in the GLM for nests installed in succession areas. A minimum probability level of $p<0.05$ was considered in all statistical analyses.

\section{RESULTS}

We collected data for a total of 152 experimental nests, including 67 in reclaimed areas and 85 in succession areas (Table 1). Although the rate of predation of experimental nests in 
succession areas was lower, it did not differ significantly from the rate of predation of experimental nests in reclaimed areas $\left(\chi^{2}=0.144, d f=1, p=0.7046\right)$. The predation rate did not differ significantly between both succession areas $\left(\chi^{2}=0.6684, d f=1, p=0.4136\right)$ nor was there a significant difference between the rate of predation of elevated and ground nests installed in succession areas $\left(\chi^{2}=1.016, d f=1, p=0.3135\right)$.

Table 1: Numbers of predated and non-predated experimental nests and the percentage of predation in each type of environment and depending on the nest height above the ground for nests installed in succession areas. Differences in the number of predated and non-predated nests were tested by the chi-squared test of good fit.

\begin{tabular}{|c|c|c|c|c|c|c|c|}
\hline Nest site/type & $\begin{array}{l}\text { Number of } \\
\text { predated } \\
\text { nests }\end{array}$ & $\%$ & $\begin{array}{l}\text { Number of } \\
\text { non-predated } \\
\text { nests }\end{array}$ & $\%$ & $\chi^{2}$ & $d f$ & $p$ \\
\hline $\begin{array}{l}\text { Reclaimed sites } \\
\text { total }\end{array}$ & 62 & 92.5 & 5 & 7.5 & 48.493 & 1 & $<0.0001$ \\
\hline $\begin{array}{l}\text { Successional sites } \\
\text { total }\end{array}$ & 76 & 89.4 & 9 & 10.6 & 55.682 & 1 & $<0.0001$ \\
\hline - northern site & 35 & 85.4 & 6 & 14.6 & 20.512 & 1 & $<0.0001$ \\
\hline - southern site & 41 & 93.2 & 3 & 6.8 & 32.818 & 1 & $<0.0001$ \\
\hline - ground nests & 41 & 85.4 & 7 & 14.6 & 24.083 & 1 & $<0.0001$ \\
\hline - elevated nests & 35 & 94.6 & 2 & 5.4 & 29.432 & 1 & $<0.0001$ \\
\hline
\end{tabular}

Table 2: Numbers and percentages of experimental nests divided according to their potential nest predators, depending on the type of research site and the nest height above the ground for nests installed in succession areas. Differences in the number of nests were tested by the chi-squared test of good fit.

\begin{tabular}{|c|c|c|c|c|c|c|c|}
\hline \multirow[b]{2}{*}{ Nest site/type } & \multicolumn{2}{|c|}{ Aves } & \multicolumn{2}{|c|}{ Mammalia } & \multirow[b]{2}{*}{$\chi^{2}$} & \multirow[b]{2}{*}{$d f$} & \multirow[b]{2}{*}{$p$} \\
\hline & $\begin{array}{r}\text { Number of } \\
\text { predated } \\
\text { nests }\end{array}$ & $\%$ & $\begin{array}{r}\text { Number of } \\
\text { predated } \\
\text { nests }\end{array}$ & $\%$ & & & \\
\hline $\begin{array}{l}\text { Reclaimed sites } \\
\text { total }\end{array}$ & 23 & 46.0 & 27 & 54.0 & 0.320 & 1 & 0.5716 \\
\hline $\begin{array}{l}\text { Successional sites } \\
\text { total }\end{array}$ & 55 & 74.3 & 19 & 25.7 & 17.514 & 1 & $<0.0001$ \\
\hline - northern site & 21 & 63.6 & 12 & 36.4 & 2.455 & 1 & 0.1172 \\
\hline - southern site & 34 & 82.9 & 7 & 17.1 & 17.780 & 1 & $<0.0001$ \\
\hline - ground nests & 26 & 65.0 & 14 & 35.0 & 3.600 & 1 & 0.0578 \\
\hline - elevated nests & 29 & 85.3 & 5 & 14.7 & 16.941 & 1 & $<0.0001$ \\
\hline
\end{tabular}

We also determined a potential predator in 124 experimental nests (Table 2). Although mammals were slightly predominating in the reclaimed areas, the ratio between bird and mammal predators was almost balanced and did not differ significantly. In contrast, birds significantly dominated over mammals in the succession areas. The difference in the proportional representation of both taxonomic groups in each type of environment was statistically significant $\left(\chi^{2}=9.081, d f=1, p=0.0026\right)$. In the northern succession area, the 
predominance of birds over mammals was statistically insignificant, while in the southern area it was statistically significant. The proportional representation of individual taxonomic groups did not differ significantly between succession areas $\left(\chi^{2}=2.626, d f=1, p=0.1051\right)$. For ground nests installed in succession areas, the predominance of bird predators was weakly inconclusive, while it was strongly significant in elevated nests. The difference in the proportional representation of predators was not as insignificant between the two types of nests $\left(\chi^{2}=2.974, d f=1, p=0.0846\right)$

The average value of nest concealment in reclaimed areas $(36.7 \%)$ was significantly lower than in nests located in succession areas $(47.2 \%)(t=-2.663, d f=150, p=0.0086)$.

In both GLMs (Table 3), none of the observed predictors clearly demonstrated the predation of experimental nests.

Table 3: Separate generalised linear model for experimental nests located in reclaimed areas and succession areas. The parameters were tested by the chi-squared test.

\begin{tabular}{lccccc}
\hline & Estimate & Std. Error & $d f$ & Deviance & $p$ \\
\hline $\begin{array}{l}\text { Reclaimed site nests } \\
\text { Distance from the } \\
\text { reclamation/succession edge }\end{array}$ & & & & & \\
Nest concealment & 0.0007 & 0.0030 & 1 & 35.492 & 0.8046 \\
Successional site nests & -0.0049 & 0.0178 & 1 & 35.508 & 0.7815 \\
Distance from the & & & & & \\
reclamation/succession edge & & & & & \\
Nest concealment & 0.0049 & 0.0065 & 1 & 54.645 & 0.4445 \\
Nest height & 0.0153 & 0.0193 & 1 & 54.693 & 0.4262 \\
\hline
\end{tabular}

\section{DISCUSSION}

The studied succession areas represented habitats close to nature different from the surrounding predominantly agriculturally reclaimed area of the spoil heap, transformed into regularly managed grasslands. Therefore, we assumed that these different environments might differ in the risk of predation of artificial nests (e.g. Seitz \& Zegers, 1993) or interact in one or both directions (regardless of whether positively or negatively) (Blitzer et al., 2012; Schneider et al., 2013). The succession areas could provide nesting birds with better vegetation cover for their nests and protection from predators, thereby, positively influencing the risk of nest predation (Götmark et al., 1995; Burhans \& Thompson III, 2001; Weidinger, 2002; Whittingham \& Evans, 2004). Or, on the contrary, they themselves could act negatively and be the source of predation pressure directed to their surroundings (Andrén, 1992; Söderström et al., 1998; van Der Vliet et al., 2008; Reino et al., 2010; Ludwig et al., 2012). We also considered the possible presence of an edge effect on the predation of experimental nests in the environment with a steep gradient in primary productivity on their divide (e.g. Angelstam, 1986).

Although the succession areas provided better cover for experimental nests compared to nests placed in reclaimed areas and the experimental nests placed there had lower predation rates, the difference between the predation levels found was not statistically significant. The predation rates found were very high in both types of studied sites $(89.4 \%$ and $92.5 \%$, respectively) compared to similar previous studies (see, for example; Paton, 1994), but not 
Novák J., Hendrychová M.: Does experimental non-reclaimed sites differ from technically reclaimed areas in the risk of artificial bird nest predation? A case study in Radovesická spoil heap

isolated (e.g. Sanchez-Oliver et al., 2014). However, none of the predictors investigated in the study, and primarily aimed at monitoring the potential interaction between the investigated sites explained the predation rate conclusively. The influence of succession areas on the predation of experimental nests located in their surroundings in a technically reclaimed area has not been proven. Although, according to the GLM, the probability of nest predation decreased slightly with proximity to succession areas, this tendency was very weak and inconclusive. Moreover, this dependence was also found in the opposite direction, i.e. from the edge of the succession sites into their interior. However, it was inconclusive even in this case. Thus, the influence of the edge effect at the interface of both environments was not detected (Andrén, 1995; Lahti, 2001; Batáry \& Báldi, 2004). Rather than the management of the areas, the characteristics of the habitats and spatial relationships seem to explain the high risk of nest predation. The environment of the Radovesická spoil heap consists mainly of open grassland complemented by smaller areas of scattered greenery or young forest reclamation. Such an environment promotes a high number of predator prey (personal observation) such as rodents (Rodentia) or lagomorphs (Lagomorpha) (Hulbert et al., 1996). Higher prey rates can hence lead to an increased predator frequency and activity, and consequently increased nest predation (Vickery et al., 1992; Yanes \& Suarez, 1996). The predation rate in the given habitat correlates with the abundance of nest predators in the habitat (Andrén et al., 1985). The high predator counts can then suppress or completely conceal the significant mutual influence between the neighbouring habitats, including the edge effect on their interface; the location of the nests farther from the edge does not reduce the risk of its predation (Renfrew et al., 2005). This applies in particular to bigger nest predators who are both trophic and habitat generalists and are able to enter diverse types of environments and move relatively freely between them (Gehring \& Swihart, 2003). In addition to the food offer, the high local abundance of predators could be supported by the character of the heap as a relatively large area without a permanent human presence surrounded by a predominantly agricultural or urbanized landscape, attracting predators (and the prey) as their temporary or permanent habitat (refugia), mainly in inner islands of forest stands, including both successional sites (Müller et al., 2017).

The composition of presumable predators in both types of environments corresponded to the assumption of greater significance of bird nest predators in enclosed (e.g. forest) habitats, as birds seek prey visually. To be able to do this, they need elevated viewpoints, such as tree stands to search for prey (Angelstam, 1986; Paton, 1994; van Der Vliet et al., 2008). In the reclaimed areas, most of which were large-scale permanent grasslands, the ratio between birds and mammals was balanced (mammals even slightly dominated). However, in the succession sites formed by dominant natural succession wood forests, birds significantly predominated. Birds were also significant presumable predators of elevated nests (Söderström et al., 1998), which may be less accessible or even inaccessible to some mammalian species. (Ludwig et al., 2012). The inconclusiveness of the higher prevalence rate of elevated sites compared to the ground nests corresponds to the differing results of previous studies (e.g., Martin, 1993; Suvorov et al., 2014) and probably depends on the composition of the local nest predator community. When mammals are the dominant nest predators, ground nests are more predated and vice versa (Ratti \& Rees, 1988).

Direct observations and signs of presence made it possible to define the range of potential bird nest predators active in the study area. Of the bird predators, it was mainly Eurasian jay (Garrulus glandarius), especially in forest stands in the territory of succession sites. In open habitats, there were common buzzard (Buteo buteo) and western marsh-harrier (Circus aeruginosus), which was tied to several artificial water reservoirs built during the operation 
and reclamation of the heap. Among mammals, it was a highly abundant wild boar (Sus scrofa), as well as red fox (Vulpes vulpes), European badger (Meles meles) and especially in forest stands European pine marten (Martes martes). Although we did not directly observe the species composition, the above list of nest predators corresponds well to the findings of other studies in Central Europe (e.g. Šálek et. al., 2004 or Purger et al., 2004b and other studies in Batáry \& Báldi, 2004). Also predation of nests by other species of corvids (Corvidae) (van Der Vliet et al., 2008; Bravo et al., 2020) and small rodents could be expected (Remeš, 2005; Ludwig et al., 2012).

\section{CONCLUSIONS}

The succession sites represent two mutually isolated naturally predominantly forested areas, situated within artificially established and managed permanent grasslands. In fact, these are fragmented forest habitats within an agricultural landscape matrix. Based on the assumption that the technically reclaimed area is under great predation pressure, which was reflected in the high rate of predation of experimental nests located there, the succession areas themselves may be under the influence of their surroundings, i.e. under the influence of the landscape matrix (Forman, 1995; Poulin and Villard, 2011). Although they may offer an environment providing potentially better nesting shelter compared to open grasslands, we believe that the two relatively small and isolated (referring to the total area of the spoil heap) areas may not provide enough of an inward environment without or with at least a limited influence (e.g. by predation pressure), originating from adjacent reclaimed areas (Begon et al., 1986; Forman \& Godron, 1986).

Our case study is the initial insight into the functioning of nest predation risk at reclaimed post-mining sites. It is appropriate to extend the experiment on other similar post-mining sites - preferably those that once again contain habitats with spontaneous succession within their territory.

\section{ACKNOWLEDGEMENT}

We are grateful to anonymous reviewers for their comments that have improved the quality of the manuscript. Thank you to Věra Nováková, Miroslav Novák and Oldřich Rajchl for their help in the fieldwork. We would like to thank Miroslav E. Šálek for his expert consultation. We also thank MERIVA TRANSLATIONS s.r.o. for translation services. This study was supported by the Internal Grant Agency of the Faculty of Environmental Sciences of the Czech University of Life Sciences in Prague (grant number 20184214).

\section{CONFLICTS OF INTEREST}

The authors declare no conflict of interest.

\section{REFERENCES}

Angelstam, P. (1986). Predation on ground-nesting birds' nests in relation to predator densities and habitat edge. Oikos 47:365-373 doi: 10.2307/3565450.

Andrén, H. (1992). Corvid density and nest predation in relation to forest fragmentation: a landscape perspective. Ecology 73:794-804 doi: 10.2307/1940158. 
Novák J., Hendrychová M.: Does experimental non-reclaimed sites differ from technically reclaimed areas in the risk of artificial bird nest predation? A case study in Radovesická spoil heap

Andrén, H. (1995). Effects of landscape composition on predation rates at habitat edges. In: Hansson L, Fahrig L, Merriam G (eds) Mosaic Landscapes and Ecological Processes (pp 225-255). Springer, Dordrecht.

Andrén, H., Angelstam, P., Lindstrom, E., Widen, P. (1985). Differences in predation pressure in relation to habitat fragmentation: an experiment. Oikos 45:273-277 doi: $10.2307 / 3565714$.

Baasch, A., Kirmer, A., Tischew, S. (2012). Nine years of vegetation development in a postmining site: effects of spontaneous and assisted site recovery. Journal of Applied Ecology 49:251-260 doi: 10.1111/j.1365-2664.2011.02086.x.

Batáry, P., Báldi, A. (2004). Evidence of an edge effect on avian nest success. Conservation Biology 18:389-400 doi: 10.1111/j.1523-1739.2004.00184.x

Begon, M., Harper, J.L., Townsend, C.R. (1986). Ecology. Individuals, populations and communities. Blackwell scientific publications. Oxford.

Bejček, V., Št'astný, K. (1984). The succession of bird communities on spoil banks after surface brown coal mining. Ekologia polska-polish journal of ecology 32:245-259.

Blitzer, E.J., Dormann, C.F., Holzschuh, A., Klein, A., Rand, T.A., Tscharntke, T. (2012). Spillover of functionally important organisms between managed and natural habitats. Agriculture, Ecosystems and Environment 146:34-43 doi: 10.1016/j.agee.2011.09.005.

Bradshaw, A.D., Hüttl, R.F. (2001). Future minesite restoration involves a broader approach. Ecological Engineering 17:87-90 doi: 10.1016/S0925-8574(00)00149-X.

Bravo, C., Pays, O., Sarasa, M., Bretagnolle, V. (2020). Revisiting an old question: Which predators eat eggs of ground-nesting birds in farmland landscapes? Science of the Total Environment 744:1-10 doi: 10.1016/j.scitotenv.2020.140895.

Bröring, U., Wiegleb, G. (2005). Soil zoology II: Colonization, distribution, and abundance of terrestrial Heteroptera in open landscapes of former brown coal mining areas. Ecological Engineering 24:135-147 doi: 10.1016/j.ecoleng.2004.12.015.

Burhans, D.E., Thompson, III F.R. (2001). Relationship of songbird nest concealment to nest fate and flushing behavior of adults. The Auk 118:237-242 doi: 10.1642/0004-8038(2001) 118[0237:ROSNCT]2.0.CO;2.

Chalfoun, A.D., Thompson, F.R., Ratnaswamy, M.J. (2002). Nest predators and fragmentation: A review and meta-analysis. Conservation Biology 16:306-318 doi: 10.1046/j.1523-1739.2002.00308.x.

Clavero, M., Brotons, L., Herrando, S. (2011). Bird community specialization, bird conservation and disturbance: The role of wildfires. Journal of Animal Ecology 80:128-136 doi: 10.1111/j.1365-2656.2010.01748.x.

Donovan, T.M., Jones, P.W., Annand, E.M., Thompson, III F.R. (1997). Variation in local-scale edge effects: mechanisms and landscape context. Ecology 78:2064-2075 doi: 10.1890/0012-9658(1997)078[2064:VILSEE]2.0.CO;2.

Forman, R.T.T. (1995). Land Mosaics: The Ecology of Landscapes and Regions. Cambridge University Press.

Forman, R.T.T., Godron, M. (1986). Landscape ecology. John Wiley \& Sons, New York.

Gates, J.E., Gysel, L.W. (1978). Avian nest dispersion and fledging success in field-forest ecotones. Ecology 59:871-883 doi: 10.2307/1938540.

Gehring, T.M., Swihart, R.K. (2003). Body size, niche breadth, and ecologically scaled 
responses to habitat fragmentation: Mammalian predators in an agricultural landscape. Biological Conservation 109:283-295 doi: 10.2307/1938540.

Götmark, F., Blomqvist, D., Johansson, O.C., Bergkvist, J. (1995). Nest site selection: A trade-off between concealment and view of the surroundings? Journal of Avian Biology 26:305-312 doi: 10.2307/3677045.

Hendrychová, M., Bogusch, P. (2016). Combination of reclaimed and unreclaimed sites is the best practice for protection of aculeate Hymenoptera species on brown coal spoil heaps. Journal of insect conservation 20:807-820 doi: 10.1007/s10841-016-9912-8.

Hendrychová, M., Svobodová, K., Kabrna, M. (2020). Mine reclamation planning and management: Integrating natural habitats into post-mining land use. Resources Policy 69:113 doi: 10.1016/j.resourpol.2020.101882.

Hendrychová, M., Šálek, M., Řehoř, M. (2009). Bird communities of forest stands on spoil heaps after brown coal mining. Sylvia 45:177-189.

Hendrychová, M., Šálek, M., Tajovský, K., Řehoř, M. (2012). Soil properties and species richness of invertebrates on afforested sites after brown coal mining. Restoration Ecology 20:561-567 doi: 10.1111/j.1526-100X.2011.00841.x.

Hodačová, D., Prach, K. (2003). Spoil heaps from brown coal mining: Technical reclamation versus spontaneous revegetation. Restoration Ecology 11:385-391 doi: 10.1046/j.1526100X.2003.00202.x.

Hulbert, I.A., Iason, G.R., Racey, P.A. (1996). Habitat utilization in a stratified upland landscape by two lagomorphs with different feeding strategies. Journal of Aplied Ecology 33:315-324 doi: 10.2307/2404753.

Hüttl, R.F., Gerwin, W. (2005) Landscape and ecosystem development after disturbance by mining. Ecological Engineering 24:1-3. doi: 10.1016/j.ecoleng.2004.12.002.

Karr, J.R. (1968). Habitat and avian diversity on strip-mined land in east-central Illinois. The Condor 70:348-357 doi: 10.2307/1365929.

Kirmer, A., Tischew, S., Ozinga, W.A., Von Lampe, M., Baasch, A., Van Groenendael, J.M. (2008) Importance of regional species pools and functional traits in colonization processes: predicting re-colonization after large-scale destruction of ecosystems. Journal of Applied Ecology 45:1523-1530 doi: 10.1111/j.1365-2664.2008.01529.x.

Lahti, D.C. (2001). The "egde effects on nest predation" hypothesis after twenty years. Biological Conservation 99:365-374 doi: 10.1016/S0006-3207(00)00222-6.

Ludwig, M., Schlinkert, H., Holzschuh, A., Fischer, C., Scherber, C., Trnka, A., Tscharntke, T., Batáry, P. (2012). Landscape-moderated bird nest predation in hedges and forest edges. Acta Oecologica 4:50-56 doi: 10.1016/j.actao.2012.08.008.

Macdonald, S.E., Landhäusser, S.M., Skousen, J., Franklin, J., Frouz, J., Hall, S., Jacobs, D.F., Quideau, S. (2015). Forest restoration following surface mining disturbance: challenges and solutions. New Forests 46:703-732 doi: 10.1007/s11056-015-9506-4.

Maier, A.T.J., Degraaf, R.M. (2000). Predation on Japanese quail vs. House sparrow eggs in artificial nests: small eggs reveal small predators. Condor 102:325-332 doi: 10.1650/0010-5422(2000)102[0325:POJQVH]2.0.CO;2.

Major, R.E. (1990). The effect of human observers on the intensity of nest predation. Ibis 134:608-612. doi: 10.1111/j.1474-919X.1990.tb00285.x.

Major, R.E., Kendal, C.E. (1996). The contribution of artificial nest experiments to understanding avian reproductive success: a review of methods and conclusions. Ibis 
Novák J., Hendrychová M.: Does experimental non-reclaimed sites differ from technically reclaimed areas in the risk of artificial bird nest predation? A case study in Radovesická spoil heap

138:298-307 doi: 10.1111/j.1474-919X.1996.tb04342.x.

Martin, T.E. (1993). Nest predation and nest sites: new perspectives on old patterns. BioScience 43:523-532 doi: 10.2307/1311947.

Moudrý, V., Moudrá, L., Barták, V., Bejček, V., Gdulová, K., Hendrychová, M., Moravec, D., Musil, P., Rocchinia, D., Št’astný, K., Volf, O., Šálek, M. (2021). The role of the vegetation structure, primary productivity and senescent vegetation derived from airborne LiDAR and hyperspectral data for bird's diversity and rarity on restored site. Landscape and Urban Planning 210:1-12 doi: 10.1016/j.landurbplan.2021.104064.

Müller, A., Dahm, M., Bøcher, P.K., Root-Bernstein, M., Svenning, J.C. (2017). Large herbivores in novel ecosystems - Habitat selection by red deer (Cervus elaphus) in a former brown-coal mining area. PLoS ONE 12:1-20 doi: 10.1371/journal.pone.0177431.

Novák, J. (2017). Edge effect on bird nest predation on Radovesice spoil heap. Master thesis, Faculty of Environmental Sciences, Czech University of Life Sciences Prague.

Pärt, T., Wretenberg, J. (2002). Do artificial nests reveal relative nest predation risk for real nests? Journal of Avian Biology 33:39-46 doi: 10.1034/j.1600-048X.2002.330107.x.

Paton, P.W.C. (1994). The effect of edge on avian nest success: How strong is the evidence? Conservation Biology 8:17-26 doi: 10.1046/j.1523-1739.1994.08010017.x.

Poulin, J-F., Villard, M-A. (2011). Edge effect and matrix influence on the nest survival of an old forest specialist, the Brown creeper (Certhia americana). Landscape Ecology 26:911922 doi: 10.1007/s10980-011-9615-1.

Prach, K., Hobbs, R.J. (2008). Spontaneous succession versus technical reclamation in the restoration of disturbed sites. Restoration Ecology 16:363-366 doi: 10.1111/j.1526-100X. 2008.00412.x.

Prach, K., Pyšek, P. (2001). Using spontaneous succession for restoration of human-disturbed habitats: Experience from Central Europe. Ecological Engineering 17:5562 doi: 10.1016/S0925-8574(00)00132-4.

Prach, K., Řehounková, K., Řehounek, J., Konvalinková, P. (2011). Ecological restoration of central european mining sites: A summary of a multi-site analysis. Landscape Research 36:263-268 doi: 10.1080/01426397.2010.547571.

Purger, J.J., Mészáros, L.A., Purger, D. (2004a). Predation on artificial nests in post-mining recultivated area and forest edge: Contrasting the use of plasticine and quail eggs. Ecological Engineering 22:209-212 doi: 10.1016/j.ecoleng.2004.05.004.

Purger, J.J., Mészáros, L.A., Purger, D. (2004b). Ground nesting in recultivated forest habitats - a study with artificial nests. Acta Ornithologica 39:141-145 doi: 10.3161/0001645044213866.

$\mathrm{R}$ Development Core Team (2018). $R$ version 3.5.1. The $\mathrm{R}$ Foundation for Statistical Computing Esri Inc. Vienna, Austria.

Ratti, J.T., Reese, K.P. (1988). Preliminary test of the ecological trap hypothesis. The Journal of Wildlife Management 52:484-491 doi: 10.2307/3801596.

Reino, L., Porto, M., Morgado, R., Carvalho, F., Mira, A., Beja, P. (2010). Does afforestation increase bird nest predation risk in surrounding farmland? Forest Ecology and Management 260:1359-1366 doi: 10.1016/j.foreco.2010.07.032.

Remeš, V. (2005). Birds and rodents destroy different nests: a study of Blackcap Sylvia atricapilla using the removal of nest. Ibis 147:213-216 doi: 10.1111/j.1474-919x. 
2004.00339.x.

Renfrew, R.B., Ribic, C.A., Nack, J.L. (2005). Edge avoidance by nesting grassland birds: a futile strategy in a fragmented landscape. The Auk 122:618-636 doi: 10.1642/0004-8038 (2005)122[0618:EABNGB]2.0.CO;2.

Ricklefs, R.E. (1969). An analysis of nesting mortality in birds. Smithsonian Contributions to Zoology 9:1-48.

Šálek, M. (2012). Spontaneous succession on opencast mining sites: Implications for bird biodiversity. Journal of Applied Ecology 49:1417-1425 doi: 10.1111/j.1365-2664. 2012.02215.x.

Šálek, M., Svobodová, J., Bejček, V., Albrecht, T. (2004). Predation on artificial nests in relation to the numbers of small mammals in the Krušné hory Mts, the Czech Republic. Folia Zoologica 53:312-318.

Sánchez-Oliver, J.S., Rey Benayas, J.M., Carrascal, L.M. (2014). Local habitat and landscape influence predation of bird nests on afforested Mediterranean cropland. Acta Oecologica 58:35-43 doi: 10.1016/j.actao.2014.05.001.

Schneider, G., Krauss, J., Steffan-Dewenter, I. (2013). Predation rates on semi-natural grasslands depend on adjacent habitat type. Basic and Applied Ecology 14:614-621 doi: 10.1016/j.baae.2013.08.008.

Seitz, L.C., Zegers, D.A. (1993). An experimental study of nest predation in adjacent deciduous, coniferous and successional habitats. The Condor: Ornithological Applications 95:297-304 doi: 10.2307/1369352.

Söderström, B., Pärt, T., Rydén, J. (1998). Different nest predator faunas and nest predation risk on ground and shrub nests at forest ecotones: an experiment and a review. Oecologia 117:108-118 doi: 10.1007/s004420050638.

Stephens, S.E., Koons, D.N., Rotella, J.J., Willey, D.W. (2004). Effects of habitat fragmentation on avian nesting success: A review of the evidence at multiple spatial scales. Biological Conservation 115:101-110 doi: 10.1016/S0006-3207(03)00098-3.

Suvorov, P., Svobodová, J., Albrecht, T. (2014). Habitat edges affect patterns of artificial nest predation along a wetland-meadow boundary. Acta Oecologica 59:91-96 doi: 10.1016/j.actao.2014.06.003.

Tischew, S., Kirmer, A. (2007). Implementation of basic studies in the ecological restoration of surface-mined land. Restoration Ecology 15:321-325 doi: 10.1111/j.1526 -100X.2007.00217.x.

van Der Vliet, R.E., Schuller, E., Wassen, M.J. (2008). Avian predators in a meadow landscape: consequences of their occurrence for breeding open-area birds. Journal of Avian Biology 39:523-529. doi: 10.1111/j.0908-8857.2008.04310.x.

Vickery, P.D., Hunter, M.L., Wells, J.V. (1992). Evidence of incidental nest predation and its effects on nests of threatened grassland birds. Oikos 63:281-288 doi: 10.2307/3545389.

Weidinger, K. (2002). Interactive effects of concealment, parental behaviour and predators on the survival of open passerine nests. Journal of Animal Ecology 71:424-437 doi: 10.1046/j.1365-2656.2002.00611.x.

Whelan, C.J., Dilger, M.L., Robson, D., Hallyn, N., Dilger, S. (1994). Effects of olfactory cues on artificial-nest experiments. Auk 111:945-952 doi: 10.2307/4088826.

Wilcox, B.A., Murphy, D.D. (1985). Conservation strategy: The effects of fragmentation on extinction. The American Naturalist 152:879-887 doi: 10.1086/284386. 
Novák J., Hendrychová M.: Does experimental non-reclaimed sites differ from technically reclaimed areas in the risk of artificial bird nest predation? A case study in Radovesická spoil heap

Whittingham, M.J., Evans, K.L. (2004). The effects of habitat structure on predation risk of birds in agricultural landscapes. Ibis 146:210-220 doi: 10.1111/j.1474-919X.2004.00370.x. Yanes, M., Suárez, F. (1996). Incidental nest predation and lark conservation in an Iberian semiarid shrubsteppe. Conservation Biology 10:881-887 doi: 10.1046/j.1523-1739. 1996.10030881.x.

Zanette, L. (2002). What do artifical nests tell us about nest predation? Biological Conservation 103:323-329 doi: 10.1016/S0006-3207(01)00143. 